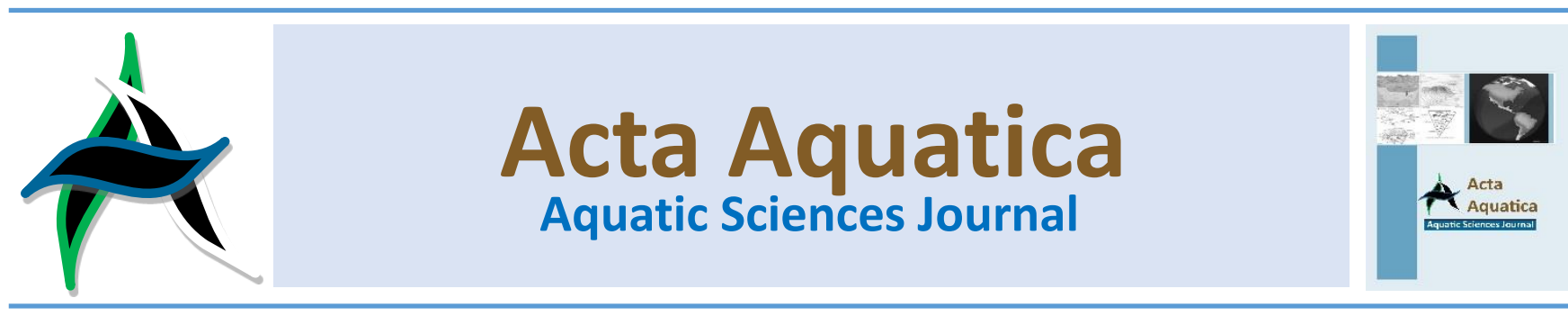

\title{
Penambahan kalsium tulang ikan kambing-kambing (Abalistes stellaris) pada pakan untuk keberhasilan gastrolisasi udang galah (Macrobrachium rosenbergii)
}

\section{Addition of calcium from kambing-kambing fish (Abalistes stellaris) bones on feed for the gastrolysis success of giant prawn (Macrobrachium rosenbergii)}

\author{
Ade Rizki Restari ${ }^{a, *}$, Lia Handayani ${ }^{\text {b }}$ dan Nurhayati ${ }^{\text {a }}$ \\ a Program Studi Budidaya Perairan, Fakultas Perikanan, Universitas Abulyatama, Indonesia \\ ${ }^{b}$ Program Studi Teknologi Hasil Perikanan, Fakultas Perikanan, Universitas Abulyatama, Indonesia
}

\begin{abstract}
Abstrak
Udang galah mengalami pertumbuhan setelah molting, untuk pengerasan kulit udang membutuhkan kalsium. Tulang ikan kambing-kambing mengandung banyak kalsium sehingga dapat mempercepat proses pengerasan kulit pada udang. Penelitian ini dilakukan untuk mengetahui penambahan kalsium tulang ikan kambing-kambing dapat meningkatkan pertumbuhan dan frekuensi molting udang galah. Penelitian ini menggunakan rancangan acak lengkap (RAL) dengan penambahan resirkulasi sebagai media dalam pemeliharaan kualitas air yang perlakuannya sebanyak empat perlakuan dan tiga ulangan yang terdiri dari $\mathrm{A}(0 \% \mathrm{CaO}), \mathrm{B}(1 \% \mathrm{CaO}), \mathrm{C}(2 \% \mathrm{CaO})$ dan $\mathrm{D}(3 \% \mathrm{CaO})$. Hasil penelitian menunjukkan bahwa penambahan kalsium berpengaruh nyata terhadap kelangsungan hidup udang galah yaitu A 90\%, B 95\%, C 90\% dan D 97.5\% dan pertumbuhan berat harian pada masing-masing perlakuan yaitu $A 1.76 \mathrm{~g}, \mathrm{~B} 1.72 \mathrm{~g}, \mathrm{C}$ $1.60 \mathrm{~g}$, dan $D 1.86$. Pertumbuhan panjang harian yaitu $A 1.23 \mathrm{~cm}$, $B 1.26 \mathrm{~cm}, C 1.23 \mathrm{~cm}$ dan $D 1.06 \mathrm{~cm}$ dengan frekuensi molting udang galah tertinggi yaitu C 0.75 kali/ekor, D 0.63 kali/ekor, A 0.59 kali/ekor dan yang terendah pada perlakuan B 0.45 kali/ekor.
\end{abstract}

Kata kunci: kalsium; kelangsungan hidup; pertumbuhan; udang galah

\begin{abstract}
Giant shrimp growth after the molting process, for hardening shrimp shell requires calcium. Kambing-kambing fish bones contains lots of calcium so that they do accelerate the process of hardening the shell-on shrimp. This study was conducted to detect addition of kambing-kambing fish bone calcium get increase the growth and the molting frequency of giant shrimp. This study used was Completely Randomized Design (CRD) with additions recirculation system as media a medium in maintaining water quality with four treatments and three replications consist is $\mathrm{A}(0 \% \mathrm{CaO}), \mathrm{B}(1 \% \mathrm{CaO}), \mathrm{C}(2 \% \mathrm{CaO})$ and dan $\mathrm{D}(3 \% \mathrm{CaO})$. The results showed that real participation in the survival of giant prawns, namely A 90\%, B 95\%, C $90 \%$ dan D $97.5 \%$ and daily weight growth in each treatment that is $A 1.76 \mathrm{~g}, \mathrm{~B} 1.72 \mathrm{~g}, \mathrm{C} 1.60$ $\mathrm{g}$, and D 1.86. Daily length growth that is $A 1.23 \mathrm{~cm}, B 1.26 \mathrm{~cm}, C$ $1.23 \mathrm{~cm}$ and $D 1.06 \mathrm{~cm}$ by means of molting frequency of giant shrimp had the highest of C 0.75 times/tail, D 0.63 times/individual, A 0.59 times/ individual and the lowest was by treatment B 0.45 times/individual.
\end{abstract}

Keywords: calcium; survival rate; growth; giant prawn

\footnotetext{
* Korespondensi: Program Studi Budidaya Perairan, Fakultas Perikanan, Universitas Abulyatama. Jl. Blang Bintang Lama Km 8,5, Lampoh Keudee, Aceh Besar, 23272 Provinsi Aceh, Indonesia.

Tel: +62-651-21255.

e-mail: aderistya16@gmail.com

doi: https://doi.org/10.29103/aa.v6i2.1560
}

\section{Pendahuluan}

Udang galah (Macrobrachium rosenbergii) merupakan salah satu komoditas perikanan budidaya air tawar yang memiliki nilai ekonomis tinggi (Murtidjo, 1992). Menurut Putra et al. (2010), udang galah (Macrobrachium rosenbergii) merupakan spesies asli Indonesia dan menjadi salah satu komoditas unggulan perikanan budidaya air tawar Indonesia. Produksi udang diharapkan dapat meningkatkan devisa negara dalam sektor perikanan. Selain mudah dibudidayakan udang ini juga dapat hidup di air tawar dan juga payau sehingga memudahkan proses pemeliharaan sesuai lokasi yang di inginkan. Pemasaran 
udang galah masih memiliki peluang yang besar, baik didalam negeri maupun diluar negeri. Permintaan udang galah di Indonesia baru terpenuhi $40 \%$ saja dari seluruh permintaan yang ada (Tambunan, 2009). Hal ini karena masih rendahnya jumlah produksi udang galah bila dibandingkan dengan jenis udang lainnya seperti udang windu ataupun udang vannamei (Zuhri, 2012). Produksi udang di Indonesia pada tahun 2011 mencapai 400.385 ton, kemudian pada tahun 2012 mengalami peningkatan menjadi 457.000 ton dan tahun 2013 menargetkan produksi udang ditetapkan sebesar 660.000 ton (KKP, 2013).

Pemeliharaan udang galah sering muncul permasalahan yaitu pertumbuhan lambat dan kulit yang lembek. Udang galah mengalami pertumbuhan yang lambat karena belum efesien dalam memanfaatkan energi dan materi yang terdapat dalam pakan maupun sistem pengelolaan lingkungan yang belum tepat, sehingga membutuhkan kalsium untuk membantu proses gastrolisasi. Tingkat kalsium berfluktuasi selama proses pergantian kulit berlangsung untuk proses pembentukan eksoselekton, kalsium menjadi fungsi utama dalam pembentukan khitin. Pada krustasea, pembentukan karapas baru diperankan oleh zat kitin yang dipengaruhi oleh lingkungan dan nutrien. Dalam proses metabolisme, senyawa kalsium dalam kutikula berbentuk kalsium karbonat dan fosfat.

Pertumbuhan udang berhubungan erat dengan molting, karena udang mengalami pertumbuhan setelah berganti kulit. Udang membutuhkan kalsium dalam proses pengerasan kulit melalui pengendapan kalsium dikulit. Kalsium dapat dibutuhkan dari dalam makanan dan lingkungan, namun dominannya dipengaruhi oleh pakan. Lingkungan yang ditambah kapur dengan dosis rendah diduga tidak efesien karena, proporsi energi pakan yang digunakan untuk respirasi relatif kecil sehingga sisa energi dapat digunakan untuk pertumbuhan dan dengan dosis tinggi konsumsi pakan meningkat yang membutuhkan energi yang besar untuk respirasi sehingga sisa energi respirasi digunakan untuk pertumbuhan (Zaidy et al., 2008).

Kalsium dapat diperoleh dari bahan baku tepung tulang ikan untuk membantu mempercepat proses pergantian kulit. Kondisi cangkang yang keras mengakibatkan gagal molting hingga pergantian kulit berikutnya sulit dilakukan yang menyebabkan pertumbuhan udang terhambat (Ali dan Waluyo, 2015). Berdasarkan penelitian Wilder et al. (2009) bahwa osmolaritas hemolim berkaitan erat dengan proses dan siklus moulting pada udang, di mana pada saat fase post-moult nilai osmolaritas hemolim udang sangat rendah. Kalsium berperan dalam pembentukan eksoskeleton pada udang dan mempercepat proses pergantian kulit udang sehingga udang dapat tumbuh dengan cepat bila mengkonsumi pakan. Menurut Hakim (2009) Metode penambahan kalsium pada pakan sangat efektif untuk memberikan tambahan kalsium bagi lobster, karena dengan metode ini pakan yang diberikan langsung dapat dicerna bersamaan dengan kalsium yang terdapat dalam pakan. Sumber kalsium untuk memenuhi kebutuhan udang dalam proses molting dapat dihasilkan dari limbah tulang ikan. Kadar kalsium tertinggi tepung tulang ikan ikan belida (Chitala $s p$ ) yaitu sebesar 30,93\% dengan rendemen sebesar $27,77 \%$, serta kadar abu $88,13 \%$, kadar protein 0,26\%, kadar air 3,12\%, dan kadar lemak 0,91\% (Putranto et al., 2015). Dengan tingginya kadar kalsium maka limbah tulang ikan kambing-kambing selama ini hanya dikubur dan diolah menjadi pakan ternak tanpa dimanfaatkan secara optimal. Pemanfaatan tulang ikan menjadi tepung tulang dalam bentuk kalsium sebagai bahan utama kalsium yang di aplikasikan pada pakan komersial.

Dengan menggunakan metode top down dan kalsinasi untuk mengkonversi cangkang tiram menjadi $\mathrm{CaO}$ sebagai sumber kalsium dengan rendemen 57,06 memperoleh kadar kalsium $\left(\mathrm{Ca}^{2+}\right.$ ) dari nanokalsium sebesar $56,77 \%$ (Handayani \& Syahputra, 2017).

Limbah tulang ikan kambing-kambing (Abalistes stellaris) berpotensi mempercepat proses pergantian kulit udang karena mengandung kalsium yang tinggi dan juga limbah tulang ikan tersebut belum dimanfaatkan secara menyeluruh. Penelitian in penting dilakukan dengan menggunakan kalsium tulang ikan kambing-kambing pada pakan yang bertujuan untuk mengetahui apakah penambahan kalsium tersebut dapat meningkatkan laju pertumbuhan udang alah, kelangsungan hidup dan frekuensi molting udang galah dan berapakah dosis kalsium yang baik untuk mempercepat pertumbuhan berat, panjang dan frekuensi molting.

\section{Bahan dan metode}

\subsection{Alat dan bahan}

Bahan penelitian yang digunakan adalah tulang ikan kambing-kambing (Abalistes Stellaris) yang diperoleh dari pasar Lampulo. Bahan-bahan pendukung yang dibutuhkan antara lain: kalsium tulang ikan kambing-kambing, air tawar, pellet, dan udang galah. Sedangkan alat-alat yang digunakan antara lain: akuarium, resirkulasi, arang aktif, caliper, timbangan, kamera dan serok.

\subsection{Prosedur penelitian}

Metode penelitian yang digunakan adalah metode eksperimen dengan pengambilan data secara observasi langsung. Menurut Sugiyono (2006), metode penelitian eksperimen merupakan metode penelitian yang digunakan untuk mencari pengaruh perlakuan tertentu secara sengaja dan terkontrol dalam kondisi perubahan yang terjadi.

Rancangan percobaan yang digunakan adalah Rancangan Acak Lengkap (RAL) dengan satu variabel yaitu penambahan kalsium pada pakan dengan konsentrasi masing-masing $1 \%, 2 \%$, $3 \%$ dan sebagai kontrol adalah pakan yang tidak ditambahkan kalsium dengan 4 perlakuan dan 3 ulangan.

\subsubsection{Desain wadah}

Adapun desain akuarium yang digunakan dalam penelitian ini dapat di lihat pada Gambar 1.

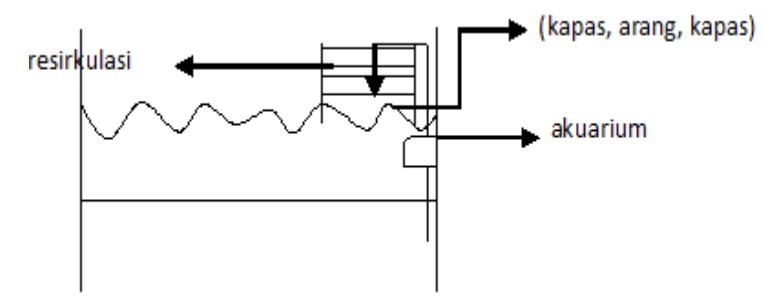

Gambar 1. Konstruksi wadah penelitian

\subsubsection{Pembuatan tulang ikan kambing-kambing}

Tulang ikan kambing-kambing yang diperoleh dari limbah perikanan dicuci agar hilangnya darah atau kotoran lain yang menempel pada tulang saat proses penyiangan. Perebusan tulang ikan kambing-kambing selama 20 menit agar daging yang menempel pada tulang dapat melunak sehingga mempermudah proses pencucian tulang ikan. Pencucian tulang dengan menyikat kotoran-kotoran yang tersisa pada tulang hingga bersih. Dilanjutkan dengan penjemuran penjemuran selama 5 hari untuk 
mengurangi kadar air didalam tulang dan memudahkan proses pengecilan ukuran. Tulang ikan dilakukan penumbukan setelah kering hingga memperoleh bentuk butiran-butiran halus yang dilanjutkan dengan miling selama 20 jam hingga lolos ayakan 100 mesh dan proses kalsinasi pada suhu $900^{\circ} \mathrm{C}$ selama 4 jam. Kalsinasi menggunakan furnance untuk mengubah kalsium karbonat menjadi kalsium oksida melalui reaksi: $\left(\mathrm{CaCO}_{3} \rightarrow \mathrm{CaO}+\right.$ $\mathrm{CO}_{2}$ ) lalu kalsium dari tulang ikan kambing-kambing siap dicampurkan pada pakan sesuai dengan kadar yang ingin ditentukan.

\subsubsection{Repeleting}

Pakan yang telah dihaluskan dicampurkan dengan kalsium dan CMC (carboxy methyl cellulose). Adapun proses pembuatan pakan mengacu (Handayani, 2018) yaitu 1\% CMC dan $70 \%$ air dari jumlah pakan dan penambahan kalsium $1 \%$ pada pakan 500 gram yang diaduk merata. Setelah merata pakan dilakukan repeleting (cetak ulang) dengan menggunakan mesin pembuat pakan. Pakan yang dicetak dipotong terlebih dahulu sebelum dilakukan penjemuran. Pakan dijemur selama 2-3 hari dibawah sinar matahari lalu disimpan didalam wadah yang kering. Untuk kadar kalsium ( $2 \%$ dan $3 \%$ ) juga menggunakan cara yang sama yaitu $1 \% \mathrm{CMC}$ dan $70 \%$ air dari jumlah pakan, namun pada pakan kontrol (0\%) hanya menambahkan $1 \%$ CMC, air $70 \%$ dari jumlah pakan tanpa penambahan kalsium. Hal ini dilakukan agar dapat membedakan perkembangan udang selama penelitian dengan memberikan kadar persentase yang berbedabeda disetiap olahan pakan.

\subsection{Parameter pengamatan}

\subsubsection{Rendemen}

Perhitungan rendemen dihasilkan dari berat kering tulang ikan yang dihasilkan dari proses kalsinasi dibagi dengan berat awal (sebelum tulang ikan dikalsinasi). Besarnya rendemen dapat dihasilkan dengan rumus:

$$
\text { Rendemen }=\frac{\text { Berat tulang ikan (akhir) }}{\text { Berat tulang ikan (awal) }} \times 100 \%
$$

Sedangkan pengujian kadar kalsium dilakukan menggunakan metode AAS (Atomic Absorbtion Spectrophotometer) di Baristand (Balai Riset dan Standarisasi).

\subsubsection{Metode untuk penentuan kalsium}

Penetapan kadar kalsium dengan menimbang sampel 8 gr lalu mengabukan. Sampel yang telah diuji kadar kalsium dilakukan pembacaan pada Atomic Absorbtion Spectrophotometer (AAS) dengan panjang gelombang 422,7 nm (Apriyantono \& Fardiaz, 1989).

\subsubsection{Tingkat kelangsungan hidup}

Menurut Goddard, (1996) dalam Effendie et al. (2006) kelangsungan hidup ikan dihitung menggunakan rumus sebagai berikut:

$$
S R=N_{t}: N_{0} \times 100 \%
$$

Keterangan :

$\mathrm{SR}=$ Kelangsungan hidup benih (\%)

$\mathrm{Nt} \quad=$ Jumlah ikan hidup diakhir pemeliharaan (ekor)

No = Jumlah ikan pada awal pemeliharaan (ekor)

\subsubsection{Pertumbuhan bobot mutlak}

Pertumbuhan bobot mutlak dihitung dengan menggunakan rumus Weatherley, (1972) dalam Dewantoro, (2001) sebagai berikut:

$$
W=W t-W_{0}
$$

Keterangan :

$\mathrm{W}=$ Pertumbuhan mutlak (g/hari)

$\mathrm{Wt}=$ Berat rata-rata pada akhir penelitian $(\mathrm{g})$

Wo = Berat rata-rata pada awal penelitian (g)

\subsubsection{Pertumbuhan panjang mutlak}

Menurut Effendie, (1997) pertumbuhan panjang mutlak dihitung dengan menggunakan rumus sebagai berikut:

$$
L=L_{t}-L_{o}
$$

Keterangan :

$\mathrm{L} \quad=$ Pertumbuhan panjang mutlak $(\mathrm{cm})$

$\mathrm{L}_{\mathrm{t}} \quad$ = Panjang udang pada akhir penelitian $(\mathrm{cm})$

$\mathrm{L}_{\mathrm{o}} \quad$ = Panjang udang pada awal penelitian $(\mathrm{cm})$

\subsubsection{Laju pertumbuhan harian}

Menurut Effendie, (1997) laju pertumbuhan harian dirumuskan sebagai berikut:

$$
\mathrm{SGR}=\frac{\mathrm{LnWt}-\mathrm{LnWo}}{\mathrm{t}} \times 100 \%
$$

Keterangan:

SGR : Laju pertumbuhan harian (\% / hari)

Wt : Bobot udang pada akhir pemeliharaan (gr)

Wo : Bobot udang pada awal pemeliharaan (gr)

$\mathrm{t}$ : Lama penelitian (hari)

\subsubsection{Frekuensi molting}

Perhitungan frekuensi molting udang menggunakan rumus (Handayani \& Syahputra, 2018) sebagai berikut:

$$
M F q=\frac{X_{\text {molt }}}{N_{\text {tot }}}
$$

$\begin{array}{lll}\text { Keterangan: } & \\ \mathrm{MFq}: & \text { Frekuensi molting (kali/ekor) } \\ \text { Xmolt }: & \text { Jumlah udang galah yang molting secara } \\ & \text { keseluruhan (kali) } \\ \text { Ntot }: & \text { Jumlah udang galah pada masa penelitian }\end{array}$

\subsection{Analisis data}

Data yang dihasilkan dari penelitian diuji dengan analisis ragam, dilakukan berdasarkan pola Rancangan Acak Lengkap (RAL). Jika dihasilkan nilai hitung lebih besar dari $F(5 \%)$ dilanjutkan dengan uji BNT.

\section{Hasil dan pembahasan}

\subsection{Karakterisasi tepung tulang ikan}

Kalsium digunakan sebagai sumber utama bahan pakan sebagai pertumbuhan yang cepat, pertumbuhan dipengaruhi 
oleh semakin seringnya udang berganti kulit. Uji kalsium dilakukan untuk mengetahui kadar (\% kalsium) dari CaO tulang ikan kambing-kambing yang diperoleh dari metode kalsinasi.

Adapun hasil uji analisis kadar kalsium dengan proses kalsinasi dapat dilihat pada tabel berikut:

Tabel 1

Karakterisasi kalsium tulang ikan kambing-kambing.

\begin{tabular}{cc}
\hline Parameter & Nilai (\%) \\
\hline Kadar kalsium & 25.20 \\
Rendemen & 49.37 \\
\hline
\end{tabular}

Limbah organik dari tulang mengandung partikel-partikel yang berupa kalsium. Kalsium yang terkandung dalam tepung tulang ikan bisa mencapai $23.72 \%$ hingga $39.24 \%$ (Handayani et al., 2012). Penentuan kadar kalsium tulang ikan kambingkambing dengan metode Atomic Absorbtion Spectrophotometer (AAS) diperoleh nilai $25.20 \%$. Hasil pengujian kalsium ini lebih rendah dibandingkan dengan penelitian Trilaksani (2006) yaitu sebesar $32.24 \%$ yang diperoleh dari tulang ikan tuna. Susanti et al. (2016) menganalisis kadar kalsium tulang ikan kembung yaitu sebesar 29.2\%. Menurut (Mukadar, 2007 dalam Rahmawati et al., 2016) kadar kalsium tulang ikan kerapu macan (Epinephelus Fuscoguttatus) memperoleh nilai sebesar 27\%. Menurut penelitian (Syah et al., 2018) nilai gizi tepung tulang ikan bandeng memperoleh kadar abu sebesar $13.26 \%$, kadar protein $2.29 \%$, kadar air sebesar $11.83 \%$, kadar fosfor $3.57 \%$ dan kadar kalsium sebesar 5.62\%. Cucikodana, (2012) menyatakan hasil uji kadar kalsium pada tepung tulang ikan gabus (Channa striata) sebesar 6,86\%. Menurut penelitian Baskoro dalam Justicia (2012) tepung tulang nila merah memiliki kandungan kalsium sebesar $9.02 \%$. Kadar kalsium tertinggi tepung tulang ikan nila yaitu sebesar 3,69\% (Novania et al., 2018).

Berdasarkan hasil penelitian sebelumnya, kadar kalsium tulang ikan kambing-kambing sebesar $25.20 \%$ sesuai dengan pernyataan Handayani et al. (2012) berkisar antara 23.72$39.44 \%$. kadar kalsium ini serupa dengan hasil penelitian Putranto et al. (2015) dan Susanti et al. (2016), hal ini disebabkan oleh adanya persamaan lingkungan (habitat). Kandungan kalsium tulang ikan air laut lebih tinggi dibandingkan dengan air tawar dikarenakan habitat yang berbeda. Susanti et al. (2016) menyatakan habitat ikan kembung di laut dengan salinitas (kadar garam) yang cukup tinggi sehingga kalsium dan kaliumnya juga tinggi dibandingkan dengan ikan gabus yang habitat hidupnya di air tawar dengan salinitas rendah. Alkalinitas mempunyai hubungan yang erat dengan kesadahan, konsentrasi total alkalinitas yang terkandung didalam air setara dengan $\mathrm{CaCO}_{3}$ yang berhubungan erat dengan berubahnya $\mathrm{pH}$. Peningkatan total alkalinitas air dipengaruhi oleh ketersediaan kadar kapur didalam perairan (Boyd, 1989 dalam Putra et al., 2010). Senyawa yang mempengaruhi salinitas dapat berupa $\mathrm{CaCO}_{3}, \mathrm{Ca}^{2+}, \mathrm{MgSO}_{4}$, $\mathrm{CaSO}_{4}$, dan $\mathrm{CaCl}$.

Kalsinasi merupakan pengeringan yang dilakukan setelah pemanasan melalui rusaknya ikatan kimia dari molekul air. Kalsinasi berlangsung pada suhu $900^{\circ} \mathrm{C}$ dalam waktu 4 jam, hal ini dilakukan agar hilangnya gugus hidroksil dan permukaan karbonat (Granados dkk, 2007) sehingga diperoleh rendemen sebesar $49.37 \%$. Reaksi yang terjadi dari kalsinasi yaitu mengubah $\mathrm{CaCO}_{3}$ menjadi $\mathrm{CaO}$ dan hilangnya gas $\mathrm{CO}_{2}$. Reaksi dari kalsinasi sebagai berikut:

$$
\mathrm{CaCO}_{3} \rightarrow \mathrm{CaO}+\mathrm{CO}_{2}
$$

Hilangnya kadar air, karbondioksida, atau gas lain semacamnya yang dilakukan melalui pemanasan dengan suhu tinggi yang tidak mencapai titik lelehnya disebut dengan kalsinasi. Menurut Akbar et al. (2018) Titik optimum kalsinasi diperoleh pada suhu $900{ }^{\circ} \mathrm{C}$ disebabkan adanya keseimbangan ideal antara suhu dan waktu pada $900^{\circ} \mathrm{C}$, berbeda dengan suhu diatas $900{ }^{\circ} \mathrm{C}$ senyawa $\mathrm{CaO}$ berubah menjadi senyawa lain sehingga kandungan $\mathrm{CaO}$ nya berkurang dan partikel dalam sampel yang dikalsinasi belum berubah menjadi $\mathrm{CaO}$ bila suhunya dibawah $900^{\circ} \mathrm{C}$.

\subsection{Pertumbuhan, kelangsungan hidup dan molting}

Berdasarkan hasil penelitian, pertumbuhan panjang harian mengalami perbedaan pada setiap perlakuan. Tingkat tertinggi pertumbuhan panjang harian udang galah terjadi pada perlakuan $\mathrm{B}(1 \% \mathrm{CaO})$ yaitu sebesar $1.26 \mathrm{~cm}$ dan tingkat terendah pertumbuhan panjang harian terjadi pada perlakuan $\mathrm{D}(3 \% \mathrm{CaO})$ sebesar $1.06 \mathrm{~cm}$ (Tabel 2). Kandungan kalsium yang tinggi dapat menghambat udang atau mempengaruhi udang dalam proses pengerasan kulit saat mengalami proses molting, molting yang tidak sempurna (gagal molting) disebabkan oleh cangkang yang keras sehingga dapat menghambat pertumbuhan panjang maupun berat udang dalam masa pemeliharaan (Holiday, 1965) dalam Darmansah, 2011).

Tabel 2

Pertumbuhan, kelangsungan hidup dan molting ikan kambing-kambing.

\begin{tabular}{lcccc}
\hline Parameter & $\begin{array}{c}\mathrm{A}(0 \%) \\
\pm S t d e v\end{array}$ & $\begin{array}{l}\mathrm{B}(1 \%) \\
\pm \text { Stdev }\end{array}$ & $\begin{array}{l}\mathrm{C}(2 \%) \\
\pm S t d e v\end{array}$ & $\begin{array}{l}\mathrm{D}(3 \%) \\
\pm \mathrm{Stdev}\end{array}$ \\
\hline $\begin{array}{l}\text { Pertumbuhan } \\
\text { panjang } \\
\text { harian (cm) }\end{array}$ & $1.23 \pm 0.40$ & $1.26 \pm 0.41$ & $1.23 \pm 0.66$ & $1.06 \pm 0.07$ \\
\hline $\begin{array}{l}\text { Pertumbuhan } \\
\text { berat harian } \\
\text { (gr) }\end{array}$ & $1.76 \pm 0.78$ & $1.72 \pm 0.47$ & $1.60 \pm 0.21$ & $1.86 \pm 0.26$ \\
\hline $\begin{array}{l}\text { Kelangsungan } \\
\text { hidup (\%) }\end{array}$ & $90 \pm 0.00$ & $95 \pm 0.00$ & $90 \pm 0.00$ & $97.5 \pm 3.54$ \\
\hline $\begin{array}{l}\text { Laju } \\
\text { pertumbuhan } \\
\text { harian (\%) }\end{array}$ & $1 \pm 0.08$ & $2 \pm 0.59$ & $2 \pm 0.66$ & $2 \pm 0.32$ \\
\hline $\begin{array}{l}\text { Frekuensi } \\
\text { molting } \\
\text { (kali/ekor) }\end{array}$ & $0.59 \pm 1.24$ & $0.45 \pm 1.81$ & $0.75 \pm 2.86$ & $0.63 \pm 2.83$ \\
\hline
\end{tabular}

Aktivitas makan udang meningkat setelah molting karena banyaknya energi yang terkuras saat molting sehingga udang melemah maka kanibalisme tidak dapat dihindari. Pembelanjaan energi untuk osmoregulasi jumlahnya sedikit apabila kondisi media mendekati isoosmotik sehingga memaksimalkan selera makan udang dan diduga terjadinya kompetisi memperebutkan makanan dan kanibalisme terlebih pakan tidak tersedia, sedangkan media yang tidak isoosmotik akan membutuhkan energi yang besar untuk proses osmoregulasi dan juga pertumbuhannya (Ali, 2015). Untuk mengurangi sifat kanibalisme udang setelah molting dapat diminimalisir dengan pemberian pelindung (shelter) sebagai tempat persembunyian dari serangan udang yang lain.

Pertumbuhan berat harian udang galah selama masa pemeliharaan tertinggi terjadi pada perlakuan $\mathrm{D}(3 \% \mathrm{CaO}) 1.86$ gr dengan nilai terendah pada perlakuan $\mathrm{C}(2 \% \mathrm{CaO})$ yaitu 1.60 gr. Pertambahan bobot udang dipengarui oleh banyaknya mineral yang diserap oleh tubuh untuk pertumbuhannya, namun pertambahan berat tidak selalu diikuti oleh pertambahan panjang udang. Pertambahan kalsium dengan dosis tinggi masih dapat diserap baik oleh udang. Dalam hal ini dapat dikemukakan bahwa udang dengan bobot tinggi tidak menghasilkan panjang yang sesuai dengan berat yang dicapai, karena pertambahan panjang bisa lebih cepat daripada pertambahan beratnya (allometrik negatif) (Hargiyanto et al., 2013).

Kelangsungan hidup memperoleh hasil yang berbedabeda disetiap perlakuan, hal ini diduga karena pada awal pemeliharaan udang mengalami kematian karena udang masih 
belum mampu beradaptasi dengan lingkungan yang baru, sehingga membutuhkan proses aklimatisasi yang seimbang. Perlakuan D mencapai hasil tertinggi dengan kadar kalsium 3\% $\mathrm{CaO}$, namun tidak menentukan kadar kalsium tulang ikan kambing-kambing baik untuk proses pertumbuhan ini, karena didalam pertumbuhannya juga dipengaruhi oleh tingkat kematian dan kelulushidupan udang galah pada masa pemeliharaan sehingga mengalami pertumbuhan yang tidak seragam. Pertumbuhan yang tidak seragam ini menyebabkan nilai kelangsungan hidup menjadi sama sehingga udang yang tumbuh dengan cepat akan menguasai lingkungan serta terjadinya persaingan dalam memperebutkan makanan. Pada perlakuan D udang tidak mengalami kanibalisme karena selama 45 hari masa pemeliharaan udang tidak mengalami kematian.

Keberhasilan suatu populasi organisme mampu berkembang biak dan bertahan hidup pada habitatnya tidak terlepas dari penyesuaian yang dimiliki populasi tersebut. Suatu populasi organisme untuk terus berkembang biak dan bertahan hidup pada habitat tidak terlepas dari adaptasi serta penyesuaian yang dimiliki populasi tersebut, proses pembentukan struktur tubuh, cara pergerakan, pernafasan, cara memperoleh makanan dan reproduksi merupakan habitat bagi organisme air didalam suatu perairan (Rohansyah et al., 2010).

Pertumbuhan harian udang galah mengalami peningkatan sampai akhir penelitian dengan nilai tertinggi terjadi pada perlakuan $\mathrm{D}(3 \% \mathrm{CaO})$. Penambahan kalsium pada pakan dapat diserap oleh udang dengan baik dibandingkan pakan tanpa adanya penambahan kalsium, hal ini juga berbanding lurus dengan pertambahan bobot udang galah. Pertumbuhan harian berkaitan dengan seringnya udang molting yang merupakan sifat biologis udang dalam masa periodik mulai dari telur, larva hingga dewasa. Molting dipengaruhi oleh kondisi lingkungan, aktivitas makan udang, pengaruh makanan, serta umur dimana interval molting udang muda lebih pendek daripada udang dewasa (Azis, 2008). Holiday, (1965) dalam Darmansah, (2011) yang menyatakan bahwa dengan makin tingginya kalsium (Ca) dalam media akan mendorong proses pembentukan serta pengerasan kulit udang. Pengerasan cangkang terkadang bisa menyebabkan molting yang tidak sempurna (gagal molting) dan berpengaruh terhadap pertumbuhan baik panjang maupun bobot.

Pertumbuhan udang merupakan suatu proses perpaduan antara molting dan peningkatan biomassa somatik. Pertumbuhan somatik ditentukan oleh tingkat konsumsi pakan, sedangkan lama waktu postmolting ditentukan oleh laju pengendapan kalsium di kulit. Pertumbuhan udang terjadi melalui beberapa kali proses molting. Perlakuan $\mathrm{C}(2 \% \mathrm{CaO})$ merupakan intensitas molting tertinggi yaitu sebanyak 0.75 kali/ekor dan paling sedikit terjadi pada perlakuan B ( $1 \% \mathrm{CaO})$ sebanyak 0.45 kali/ekor individu. Frekuensi molting udang berbeda jauh dengan penelitian (Zufadhillah, 2018) pakan dengan penambahan nanokalsium sebanyak $3 \%$ mengalami molting sebanyak 2.14 kali/ekor yang tidak berbeda jauh dan penelitian Handayani dan Syahputra (2018) yaitu pada spesies lobster air tawar yang diberikan penambahan $2 \%$ nanokalsium selama 60 hari masa pemeliharan mengalami molting hingga 2.71 kali/ekor.

Perbedaan nilai diatas disebabkan oleh pemberian pakan tidak tepat waktu yang dibutuhkan udang untuk pengerasan kulit udang setelah molting, kalsium yang tidak terpenuhi dapat menghambat pertumbuhan sehingga tingkat kelulushidupan tidak dapat dicegah yang mengacu pada penurunan berat tubuh udang. Keberadaan kalsium yang memadai mendukung udang galah untuk dapat melakukan molting dengan cepat dan lancar serta nafsu makan udang menjadi lebih tinggi setelah molting, karena saat sebelum moulting udang banyak membuang energi dan daya tahan tubuh menurun, sehingga untuk pemulihan energi udang membutuhkan kalsium. Selain itu jenis kalsium yang digunakan juga berbeda, pada penelitian kali ini digunakan kalsium dengan ukuran mikro. Namun demikian, kadar kalsium tertinggi tidak menentukan udang menjadi lebih sering molting, seperti pada penelitian Heriadi, (2016) menyatakan bahwa jumlah udang yang molting menjadi menurun bila sedikitnya jumlah kadar kalsium karbonat yang diberikan, namun jumlah kalsium karbonat tertinggi juga menurunkan proses molting. Penggunaan kalsium dengan kadar optimal mampu membantu udang dalam menyerap kalsium sehingga mempermudah udang untuk molting (Zaidy, 2007).

Pertumbuhan udang juga memerlukan nutrien tertentu dalam jumlah tertentu, nutrien ini meliputi protein, lemak, karbohidrat, mineral dan vitamin. Protein memegang peran utama untuk pembentukan jaringan, mengganti jaringan yang rusak dan pertumbuhan udang. Udang yang stress merupakan faktor terjadinya molting karena perubahan suhu dan ketersediaan makanan. Udang yang sering melakukan molting karena stress akan berdampak pada pertumbuhan yang tidak sempurna (Ali, 2015). Pemberian pakan yang tidak tepat waktu dapat menurunkan berat tubuh udang karena saat sesudah molting udang harus segera ditangani. Udang yang sering molting terlalu banyak menghabiskan energi untuk mencerna makanan sehingga energi untuk pertumbuhan terhambat.

Pertumbuhan akan menurun jika protein pakan tidak mencukupi atau bahkan berlebih. Kelebihan protein akan dikatabolisme menjadi energi sehingga protein yang digunakan untuk membangun jaringan tubuh hanya sedikit (NRC, 1983 dalam Heptarina et al., 2010). Alanara (1994) dalam Heptarina et al. (2010) mengemukakan bahwa pakan yang berenergi tinggi karena keberadaan lemak yang tinggi tidak hanya mengurangi konsumsi pakan tetapi juga menyebabkan pertumbuhan rendah. Hal ini diperkuat oleh Iswandi et al. (2014), kekurangan pakan akan memperlambat laju pertumbuhan, sehingga dapat menyebabkan kanibalisme, sedangkan kelebihan pakan akan mencemari perairan sehingga udang stres dan menjadi lemah serta nafsu makan udang akan menurun.

Penelitian sebelumnya menunjukan bahwa penambahan kalsium didalam pakan berpengaruh nyata $(P \leq 0,05)$ terhadap pertumbuhan dan kelangsungan hidup tokolan udang galah (Noviana, 2018). Yulihartini et al. (2016) menyimpulkan bahwa pemberian calcium hidrosida $\mathrm{Ca}(\mathrm{OH})_{2}$ dengan dosis setiap perlakuan memberikan pengaruh nyata $(p<0,05)$ terhadap pertumbuhan bobot mutlak, frekuensi molting dan laju pertumbuhan harian udang vannamei (Litopenaeus vannamei). Penambahan kalsium karbonat sebanyak $65 \mathrm{mg} / \mathrm{l}$ dengan dosis berbeda memberikan pengaruh terhadap intensitas moulting, pertumbuhan harian udang vanamei dan pertumbuhan panjang dan bobot (Heriadi \& Fitrah, 2016). Hadie, (2009) mengemukakan penggunaan kalsium dalam kadar yang berbeda berpengaruh terhadap laju pertumbuhan harian udang galah yang diberi mineral kalsium terhadap pertumbuhan udang galah.

\section{Kesimpulan}

Penelitian penambahan kalsium tulang ikan kambingkambing (Abalistes stellaris) pada pakan untuk keberhasilan gastrolisasi udang galah (Macrobrachium rosenbergii) dapat disimpulkan bahwa:

1. Penambahan kalsium tulang ikan kambing-kambing pada pakan terhadap laju pertumbuhan udang galah terbaik dengan pemberian kalsium $3 \%$ nilai $2 \%$ dan terhadap kelangsungan hidup bernilai $97.5 \%$ pada kalsium $3 \%$

2. Penambahan kalsium tulang ikan kambing-kambing pada pakan sebanyak $2 \%$ meningkatkan frekuensi molting udang galah hingga 0.75 kali/ekor. 
3. Pemberian kalsium tulang ikan kambing-kambing pada pakan sebanyak $3 \%$ meningkatkan berat tubuh udang sampai akhir pemeliharaan sebesar $0.26 \mathrm{gr}$.

4. Pemberian kalsium tulang ikan kambing-kambing pada pakan dapat meningkatkan laju pertumbuhan berat udang galah sebesar $1.86 \mathrm{gr}$ juga meningkatkan pertumbuhan panjang udang galah sebesar $1.26 \mathrm{~cm}$.

\section{Bibliografi}

Akbar, S., Ulum, M.S., Darwis, D., 2018. Penentuan Komposisi Serta Suhu Kalsinasi Optimum CaO Dari Batu Kapur Kecamatan Banawa. Journal of Science and Technology Vol 7 (1) : $30-35$.

Ali, F., Waluyo, A., 2015. Tingkat Kelangsungan Hidup dan Pertumbuhan Udang Galah (Macrobranchuim rosenbergii De Man) pada Media Bersalinitas. Limnotek. 22(1): 42-51.

Apriyantono, A.D., Budiyanto, S., Fardiaz, N.L., Puspitasari, Sedarnawati, 1989. Analisis Pangan. Bogor: PAU Pangan dan Gizi. Institut Pertanian Bogor.

Baskoro, P., 2008. Fortifikasi Tepung Tulang Nila Merah Terhadap Karakteristik Biskuit. [Skripsi]. Fakultas Perikanan dan IImu Kelautan. Unpad. Jatinangor.

Cucikodana, Y., Supriadi, A., Purwanto, B., 2012. Pengaruh perbedaan suhu perebusan dan konsentrasi $\mathrm{NaOH}$ terhadap kualitas bubuk tulang ikan gabus (Channa striata). Jurnal Fishtech. 1(1): 91-101.

Darmansah, M.A., 2011. Pertumbuhan dan Kelangsungan Hidup Lobster Air Tawar (Cherax quadricarinatus) pada Pendederan Di Dalam Bak Dengan Padat Penebaran 100 Hingga 175 ekor/m2. Institut Pertanian Bogor. Bogor.

Effendi, I., Bugri, N.J., Widanarni, 2006. Pengaruh Padat Penebaran Terhadap Kelangsungan Hidup dan Pertumbuhan Benih Ikan Gurami (Osphronemus gourami) Ukuran $2 \mathrm{~cm}$. Jurnal Akuakultur Indonesia, 5(2): 127-135.

Effendie, M.I., 1997. Biologi Perikanan. Yogyakarta: Yayasan Pustaka Nusatama.

Granados, M.L., Poves, M.D.Z., Alonso, D.M., Mariscal, R., Galisteo, F.C., Moreno-Tost, R., Santamaría, J., Fierro, J.L.G., 2007. Biodiesel from Sunflower Oil by Using Activated Calcium Oxide, Applied Catalysis B: Environmental 73: 317-326.

Hakim, R. R., 2009. Penambahan Kalsium Pada Pakan untuk Meningkatkan Frekuensi Molting Lobster Air Tawar. Vol 5. No. 1. Muhammadiyah Malang.

Handayani, A., Sulistio, G.S., Deswita, 2012. Preparasi dan Karakterisasi Hidroksiapatit Berpori Dari Tulang Ikan. Jurnal Sains Materi Indonesia Indonesian Journal of Materials Science. Vol. 14, No. 1. Hal: 47-50.

Handayani, L. Syahputra, F., 2017. Isolasi Dan Karakterisasi Nanokalsium Dari Cangkang Tiram (Crassostrea gigas). Jurnal Pengolahan Hasil Perikanan Indonesia. 20(3): 515523.
Handayani, L., Syahputra, F., 2018. Perbandingan frekuensi molting Lobster air tawar (Cherax quadricarinatus) yang diberi pakan komersil dan nanokalsium yang berasal dari cangkang tiram (Crassostrea gigas). Depik. 7(1): 42-46.

Heptarina, D., Syuprayudi, M.A., Mokoginta, I., Yaniharto, D., 2010. Pengaruh Pemberian Pakan Dengan Kadar Protein Berbeda Terhadap Pertumbuhan Yuwana Udang Putih (Litopenaeus vannamei). Departemen Budidaya Perairan. Fakultas Perikanan Dan Ilmu Kelautan. Institut Pertanian Bogor.

Heriadi, Fitrah. U., 2016. Meningkatkan Kalsium karbonat $\left(\mathrm{CaCO}_{3}\right)$ Untuk Pertumbuhan dan Kelangsungan Hidup Vannamei udang (Litopenaeus vannamei). Jurnal Perikanan dan Ilmu Kelautan. Universitas Riau. Pekanbaru. $8 \mathrm{hlm}$.

Iswandi, N., Rusliandi., Putra, I., 2014. Growth and Survival Rate of Giants Prawns (Macrobrachium rosenbergii) Universitas Riau. Riau.

Kementerian Kelautan dan Perikanan [KKP]. 2013. Indonesia Fisheries Satistic Index. [diunduh 2016 Februari 13]. http://www.kkp.go.id/index.php/arsip/c/9199/produksi -udang-bisa-capai-660.000-ton-pada-2013.

Murtidjo, B.A., 1992. Budidaya Udang Galah Sistem Monokultur. Yogyakarta: Kanisius.

Novania, A., Sumardianto, S., Wijayanti, I., 2018. Pengaruh Perbandingan Penambahan Tepung Tulang Ikan Nila (Oreochromis niloticus) Dan Bubur Rumput Laut Ulva Lactuca Terhadap Karakteristik Kerupuk. Jurnal Pengolahan dan Bioteknologi Hasil Perikanan, 6(1), 2129.

Putra, I., Rusliadi, Efizon, D., Fauzi, M., 2010. Studi Pengembangan Budidaya Udang Galah (Macrobrachium rosenbergii de man) Di Kecamatan Bukit Batu Kabupaten Bengkalis. Prosbiding Seminar Antarbangsa.

Putranto, H.F., Asikin, A.N., Kusumaningrum, I., 2016. Karakterisasi Tepung Tulang Ikan Belida (Chitala sp.) Sebagai Sumber Kalsium Dengan Metode Hidrolisis Protein. Ziraa'ah Majalah Ilmiah Pertanian, 41(1), 11-20.

Rahmawati, A.P.A., Hudaidah, S., Maharani, H.W., 2016 Pengaruh Intensitas Cahaya Selama Pemeliharaan Benih Ikan Kerapu Macan (Epinephelus Fuscoguttatus). e-Jurnal Rekayasa dan Teknologi Budidaya Perairan, 5(1), 547558.

Rohansyah, Elrifadah, Marlida., R., 2010. Kaji Banding Karakter Morfologi Dua Varian Ikan Papuyu (Anabas testudineus Bloch). Jurnal Media Sains. ISSN 20853548. Vol 2. No.1. $\mathrm{p}: 77-82$

Sugiyono, 2006. Metode Penelitian Kuantitatif, Kualitatif dan $R \& D$. Bandung: Alfabeta.

Susanti, N.N., Sukmawardani, Y., Musfiroh, I., 2016. Analisis Kalium dan Kalsium pada Ikan Kembung dan Ikan Gabus. Indonesian Journal of Pharmaceutical Science and Technology, 3(1), 26. 
Syah, D.R., Sumardianto, S., Rianingsih, L., 2018. Pengaruh Penambahan Tepung Kalsium Tulang Ikan Bandeng (Chanos chanos) Terhadap Karakteristik Kerupuk Rambak Tapioka. Jurnal Pengolahan dan Bioteknologi Hasil Perikanan, 7(1), 25-33.

Tambunan, L.A., 2009. Gurihnya Laba Udang Galah. www.lipi.go.id

Wilder, M.C., Huong, D.T.T., Jasmani, S., Jayasankar, V., Kaneko, T., Aida, K., Hatta, T., Nemoto, S., Wiginton, A., 2009 Hemolymph osmolality, ion concentration and calcium in structural organization in cuticle of the giant fresh water prawn (Macrobrachium rosenbergii) Changes with the molt cycle. J. Aquaculture, 292: 104-110.

Yulihartini, W., Rusliadi, Alawi, H., 2016. Pengaruh Penambahan Calsium Hidrosida $\mathrm{Ca}(\mathrm{OH})_{2}$ Terhadap Moulting, Pertumbuhan dan Kelulushidupan Udang Vannamei (Litopenaeus Vannamei). Universitas Riau.

Zaidy A.B., Affandi R., Kiranadi B., Praptokardiyo, K., Manalu W., 2008. Pendayagunaan kalsium media perairan dalam proses ganti kulit dan konsekuensinya bagi pertumbuhan udang galah Macrobrachium rosenbergii de Man. Jurnal IImu-IImu Perairan dan Perikanan Indonesia 15: 117-125.

Zaidy, A.B., 2007. Pendayagunaan kalsium media perairan dalam proses ganti kulit dan konsekuensinya bagi pertumbuhan udang galah (Macrobrachium rosenbergii de Man). [Disertasi]. Institut Pertanian Bogor. Bogor, $107 \mathrm{hlm}$.

Zufadhillah, S., Thaib, A., Handayani, L., 2018. Efektivitas penambahan nano $\mathrm{CaO}$ cangkang kepiting bakau (Scylla serrata) kedalam pakan komersial terhadap pertumbuhan dan frekuensi molting udang galah (Macrobrachium rosenbergii). Acta Aquatica: Aquatic Sciences Journal, 5(2), 69-74. doi: https://doi.org/10.29103/aa.v5i2.811.

Zuhri S., 2012. Produksi Udang: Tahun Ini Diprediksi Naik 10\%. [Diunduh November 14, 2012]. Tersedia pada http://www.bisnis.com/articles/produksi-udang-tahunini-diprediksi-naik-10-percent. 